I dag er pasientene sine egne og hverandres «leger», og useriøse, alternative behandlere har et godt marked. Jeg savner at flere leger og psykiatere står frem og tar et oppgjør med helsemyndighetenes mangelfulle satsing på denne pasientgruppen, og med de leger som med sine utspill er bidragsytere til det samme. Vi som har levd noen år, vet etter hvert at skråsikkerheten er kunnskapens verste fiende.

\author{
Jan Nystrøm \\ jan.nystrøm@getmail.no \\ Jan Nystrøm (f. 1944) er pensjonist. \\ Ingen oppgitte interessekonflikter. \\ Litteratur \\ 1. Bjartveit $\mathrm{K}$, Helskog EH, Kryvi PD et al. Kvinne i 30-årene med kronisk utmat- \\ telse. Tidsskr Nor Legeforen 2014; 134: 423-5.
}

\section{E.H. Helskog og medarbeider svarer:}

Takk for respons. Vårt hovedbudskap er at årsaksforhold, diagnosekriterier og behandling med dokumentert effekt for denne pasientgruppen er uavklart og mangelfull. Kompetansesenteret som etterlyses, ble opprettet i 2012 - Nasjonal kompetansetjeneste for CFS/ ME ved Oslo universitetssykehus, men vi opplever at de norske retningslinjene som finnes, gir liten støtte i den kliniske hverdagen $(1,2)$.

For å unngå at pasienter havner under feil behandlingsopplegg, er det viktig å sørge for at en psykiatrisk anamnese foreligger før diagnosen $\mathrm{CFS} / \mathrm{ME}$ vurderes. Feil diagnose kan få alvorlige konsekvenser - behandlingsintervensjonene for utmattelse og depresjon er nærmest motsatt.

Diagnostisering og behandling av pasienter med diffuse symptombilder krever at man ekskluderer en rekke lidelser. Vi mener det er svært uheldig dersom CFS/ME-diagnosen etableres for tidlig.

Vi tillater oss å spekulere litt rundt hvorvidt de ulike behandlingsoppleggene, herunder langvarige antibiotikakurer, og en del alternative intervensjoner som det finnes lite eller ingen dokumentasjon på, har effekt. Private aktører kan i dag sette utmattelsesdiagnoser uten å utelukke andre lidelser med tilsvarende symptombilder, og igangsette langvarige og kostbare behandlinger på til tider sviktende eller mangelfullt grunnlag.

\section{Espen Hauk Helskog \\ espenhauk@hotmail.com \\ Kristin Bjartveit}

Espen Hauk Helskog (f. 1977) er psykolog ved Nedre Romerike DPS, Akershus universitetssykehus.

Ingen oppgitte interessekonflikter

Kristin Bjartveit (f. 1957) er spesialist i psykiatri og overlege ved Psykiatrisk avdeling, Sørlandet sykehus, Arendal.

Ingen oppgitte interessekonflikter

\section{Litteratur}

1. Helsedirektoratet Nasjonal veileder. Pasienter med CFS/ME: Utredning, diagnostikk, behandling, rehabilitering, pleie og omsorg. Oslo: Helsedirektoratet, 2013.

2. Oslo universitetssykehus, ME/CFS-Senter. Veileder i forbindelse med utredning av pasienter der man mistenker Myalgisk encephalopati (ME)/Kronisk utmattelsessyndrom (CFS) i allmennpraksis. www.oslo-universitetssykehus.no/ SiteCollectionDocuments/Om\%20oss/Avdelinger/Medisinsk\%20klinikk/ ME-CFS/ME-utredning\%20allm\%20lege\%20 nov\%2011.pdf (7.3.2014).

\section{Re: Kiropraktorutdanning i Norge nå!}

Som studieleder ved en av landets utdanninger av fysioterapeuter kan jeg ikke la være å reagere på påstanden om at «dokumentasjonen av fysioterapi er enda dårligere enn kiropraktikk» $\mathrm{i}$ artikkelen til Stein Evensen (1). Det er en påstand helt uten rot i virkeligheten! Dette er en viktig fagdiskusjon hvor jeg forventer at seriøse deltakere forsøker å sette seg inn i realitetene.
Kronikken har mange interessante sider, og det er viktig at det settes krav til dokumentasjon i det fremtidige Helse-Norge. Fysioterapi har hatt en formidabel vekst i kunnskapsbasert dokumentasjon de siste tiårene, herunder massiv forskning. Det vil et PubMedsøk enkelt bevise. Forskning og dokumentasjon har også bidratt til en endring i praksis, selv om mye gjenstår.

\section{Håvard Østerås \\ Havard.osteras@hist.no}

Håvard Østerås (f. 1971) er studieleder ved Høgskolen i Sør-Trøndelag. Ingen oppgitte interessekonflikter.

Litteratur

1. Evensen S. Kiropraktorutdanning i Norge nå! Tidsskr Nor Legeforen - Publisert først på nett 4. mars 2014 doi: 10.4045/tidsskr.14.0121.

\section{Re: Kiropraktorutdanning i Norge nå!}

Det er hyggelig at en av de mest reflekterte artiklene om kiropraktikk i norske medier i nyere tid kommer fra en forfatter med medisinsk bakgrunn (1). Det er sjelden å se en akademisk fagperson som er så fri for gamle fordommer og utslitte kritiske argumenter.

Jeg gir min fulle tilslutning til Evensen om at det ikke er mangel på forskningsinitiativ i det kiropraktiske miljøet som er problemet, men manglende økonomisk og politisk vilje til å følge opp disse positive initiativene. Norge har store utfordringer når det gjelder sykefravær og redusert arbeidsevne som følge av muskel- og skjelettrelaterte problemer. Her trengs en meget bevisst politisk handlekraft, som støttes av økonomiske bevilgninger til forskning og utdanning.

\section{Ole Christian Kvammen}

olekiro@live.no

Ole Christian Kvammen (f. 1970) er kiropraktor ved Fokus Helse

\& Trening, Sandefjord.

Ingen oppgitte interessekonflikter.

\section{Litteratur}

1. Evensen S. Kiropraktorutdanning i Norge nå! Tidsskr Nor Legeforen - Publisert først på nett 4. mars 2014 doi: 10.4045/tidsskr.14.0121

\section{S. Evensen svarer:}

Håvard Østerås kritiserer meg for å ha påstått at «dokumentasjonen av fysioterapi er enda dårligere enn kiropraktikk». Det er pussig å bli kritisert for noe jeg ikke har skrevet. I min artikkel står det: «Det er ikke lite av dagens medisinske praksis som fortsatt mangler dokumentasjon. Innen fysioterapi står det sannsynligvis enda dårligere til.» Det er fra min side ment som kritikk av egen praksis, en kritikk som også rammer fysioterapi. Østerås har tolket dette feil og deretter vridd det til et sitat oppfunnet av ham selv. Å tillegge meg et slikt sitat, synes jeg er kritikkverdig.

En kortversjon av min mening om dokumentasjonen innen fysioterapi er at effekten og nytten av fysioterapi i forbindelse med preog postoperative tilstander er meget godt dokumentert, men samtidig er det et problem at en rekke av de metodene fysioterapeuter anvender, er dårlig dokumentert. Der dokumentasjon foreligger, vises ofte bare kortvarig effekt. Det gjelder ikke minst ved fysikalskmedisinsk opptrening knyttet til kroniske tilstander. Her forsvinner effekten ofte i løpet av kort tid etter at treningsperioden er avsluttet. Mange av de millioner kroner som refunderes fysioterapeuter på diverse private institutter etter henvisning fra lege, er ressurser som med fordel kunne vært benyttet bedre andre steder i helsevesenet.

\section{Stein Evensen}

s.a.evensen@medisin.uio.no

Stein Evensen (f. 1942) er professor emeritus.

Ingen oppgitte interessekonflikter. 